УДК 902/904

https://doi.org/10.24852/2587-6112.2021.6.87.91

\title{
ЯНТАРНАЯ ПОДВЕСКА-ПЕЧАТЬ С АРАБСКОЙ НАДПИСЬЮ ИЗ СУВАРСКОГО ГОРОДИЩА
}

\author{
(C) 2021 г. А.В. Губайдуллина
}

Работа посвящена изучению янтарной подвески-печати с арабской благопожелательной надписью, которая была найдена во время работы экспедиции А.П. Смирнова в 1935 г. на территории Суварского городища. В 1933-1937 гг. были впервые организованы и проведены стационарные исследования крупного булгарского города. В ходе работ изучены остатки оборонительных укреплений, холмы в центре городища, «глинобитные дома» и деревянные срубы, зернохранилища, кирпичное здание, представляющее собой остатки архитектурного комплекса, два могильника. Находки в культурном слое многочисленны и разнообразны: керамический материал, орудия труда, предметы быта, украшения, в том числе стеклянные и каменные бусы и подвески. Коллекции материалов из этих раскопок хранятся в Национальном музее РТ (г. Казань) и Государственном историческом музее (г. Москва). Подобная янтарная подвеска-печать является редкой находкой для любого памятника. В целом, предметы с эпиграфическими надписями немногочисленны и представляют собой большой научный интерес.

Ключевые слова: археология, Волжская Булгария, Суварское городище, арабская надпись, янтарь, подвеска-печать

\section{AMBER PENDANT-SEAL WITH ARABIC INSCRIPTION FROM SUVAR FORTIFIED SETTLEMENT}

\section{A.V. Gubaidullina}

The work was aimed at the study of an amber seal pendant with a benevolent Arabic inscription, which was found during the operation of A.P. Smirnov's expedition in 1935 in the territory of Suvar fortified settlement. Stationary studies of a large Bolgar city were initially organized and conducted in 1933-1937. The remains of defensive fortifications, hills in the center of the fortified settlement, "mud houses" and wooden log cabins, granaries, a brick building representing the remains of an architectural complex, and two burial grounds were studied. The finds from the cultural layer are numerous and diverse: ceramic material, tools, household items and jewelry, including glass and stone beads and pendants. Collections of materials from these excavations are deposited at the National Museum of the Republic of Tatarstan (Kazan) and the State Historical Museum (Moscow). This type of amber seal pendant is a rare find for any site. In general, items with epigraphic inscriptions are few and of great scientific interest.

Keywords: archaeology, Volga Bolgaria, Suvar fortified settlement, Arabic inscription, amber, pendant-seal

Суварское городище является одним из знаковых памятников домонгольской Волжской Булгарии. Краткие упоминания о Суваре и о народе сувар находятся в сочинениях арабских географов начиная с X века. Открытие самих развалин Сувара принадлежит татарскому ученому Шигабутдину Марджани (до 1885 г.). Позже, в 1893 г., местонахождение Суварского городища у с. Кузнечиха Спасского уезда подтвердил член-сотрудник Общества археологии, истории и этнографии при Казанском университете Г.Н. Ахмаров (Ахмаров, 1893).

Археологическое изучение Суварского городища производилось редко. Первые и наиболее масштабные исследования были проведены экспедицией под руководством

А.П. Смирнова в 1933-1937 гг. Коллекции материалов с этих раскопок хранятся в Национальном музее РТ (г. Казань) и Государственном историческом музее (г. Москва). В последующие годы исследования проводились экспедицией Т.А. Хлебниковой (1974-1975 гг.) и экспедицией ИЯЛИ КФАН СССР (Ф.Ш. Хузин, Р.Ф. Шарифуллин, 1990-1993 гг.).

Остатки Суварского городища находятся в 4 км к западу от с. Кузнечиха Спасского района Республики Татарстан. В настоящее время Сувар представляет собой городище подчетырехугольной формы, окруженное мощными валами и рвами протяженностью около 4,5 км. Площадь древнего города внутри укреплений составляет 64 га, а вместе с укреплениями превышает 90 га. 
В историко-археологической литературе было принято считать, что Сувар после монгольского нашествия 1236 г., так же как и Биляр, восстановился, продолжал существовать и окончательно погиб в конце XIV в. Однако среди находок из Сувара, насчитывающих многие сотни и тысячи предметов, нет ни одной вещи, которую безоговорочно можно было бы отнести к золотоордынскому времени. Это свидетельствует, скорее всего, о существовании Сувара только в $\mathrm{X}$ - первой трети ХІІІ в. (Хузин, 2006, стр. 183).

Суварское городище является малоизученным памятником домонгольской Волжской Булгарии. Но история этого города очень богата и требует планомерных археологических исследований. Археологические материалы с проведенных раскопок практически не подвергались более тщательному изучению после работ А.П. Смирнова.

В 1933-1937 гг. Алексеем Петровичем Смирновым были впервые организованы и проведены стационарные исследования крупного булгарского города. В ходе работ изучены остатки оборонительных укреплений, холмы в центре городища, «глинобитные дома» и деревянные срубы, зернохранилища, кирпичное здание, представляющее собой остатки архитектурного комплекса, два могильника. Находки в культурном слое многочисленны и разнообразны: керамический материал, орудия труда, предметы быта, украшения. В том числе стеклянные и каменные бусы и подвески.

Объектом данного исследования является янтарная подвеска-печать с арабской надписью (ГИМ, оп. 2189, № 1619) с Суварского городища. Данное изделие было обнаружено на раскопе VII (1935 г.) в сооружении № 16 в ходе работ экспедиции А.П. Смирнова (Смирнов, 1941, стр. 170), которое Алексей Петрович относит к раннему периоду существования города, а также обозначает особое место этой печати в находках наряду с серебряной монетной гривной булгарского типа и татарской монетой. К сожалению, более подробных данных о находке этой подвески и сопутствующем материале из сооружения № 16 пока найти не удалось.

Подвеска (рис. 1) имеет каплевидную форму с плоским основанием, в сечении представляет собой восьмигранник, в верх- ней части находятся два перпендикулярных канала для подвешивания. Изготовлена из янтаря желто-оранжевого цвета. Качество выделки достаточно высокое: симметричные грани, тщательные полировка и шлифовка. У подвески утрачена верхняя часть - сколота по каналам. Общая высота подвески 2,89 см, нижнее основание имеет сечение $1,49 \times 1,51$ см, сечение верхней части (по длине каналов) $-1,02 \times 0,95$ см, диаметр отверстий каналов - 0,2 см. На нижнем основании подвески процарапана надпись в одну строчку из пяти знаков с волнистыми линиями по краям и одним кружком циркульного орнамента, который был повсеместно распространен на территории Волжской Булгарии. Надпись изображена зеркально и достаточно схематично, несет в себе охранную функцию с пожеланием благополучия, здоровья, защиты от сглаза. Надпись арабская:

\section{Транслитерация \\ йә сәлам йә

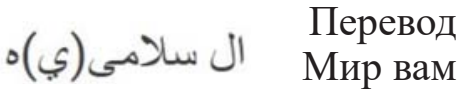 \\ Транслитеращчия \\ Перевод \\ й сафиә ايى(ي)• سافى(ي)• Святая София ${ }^{1}$}

Так как надпись не очень четкая, может быть несколько прочтений с ударениями на разные слоги.

В 30-е гг. советский археолог Алексей Иванович Тереножкин определил надпись как «Арслан» (Смирнов, 1941, стр. 170).

На раскопах, кроме данной подвески, были найдены кусочки янтаря-сырца и изделия с неоконченной обработкой, что говорит о возможном местном производстве. Что также подтверждается находками янтаря-сырца на многих других крупных домонгольских памятниках. Форма данной подвески-печати нехарактерна для русских памятников. В целом ввиду достаточной легкости обработки янтаря на территории Волжской Булгарии более разнообразны формы изделий с ориентацией на местного потребителя. На это также указывает Р.Л. Розенфельдт (Розенфельдт, 1978, стр. 208). Из всех изученных мною изделий из камня и органических материалов подобных форм встречено не было.

Самым лучшим считался янтарь, который добывался в Балтийско-Днепровской янтароносной провинции. И на прибалтийский, как на самый лучший янтарь, указывал Бируни: 

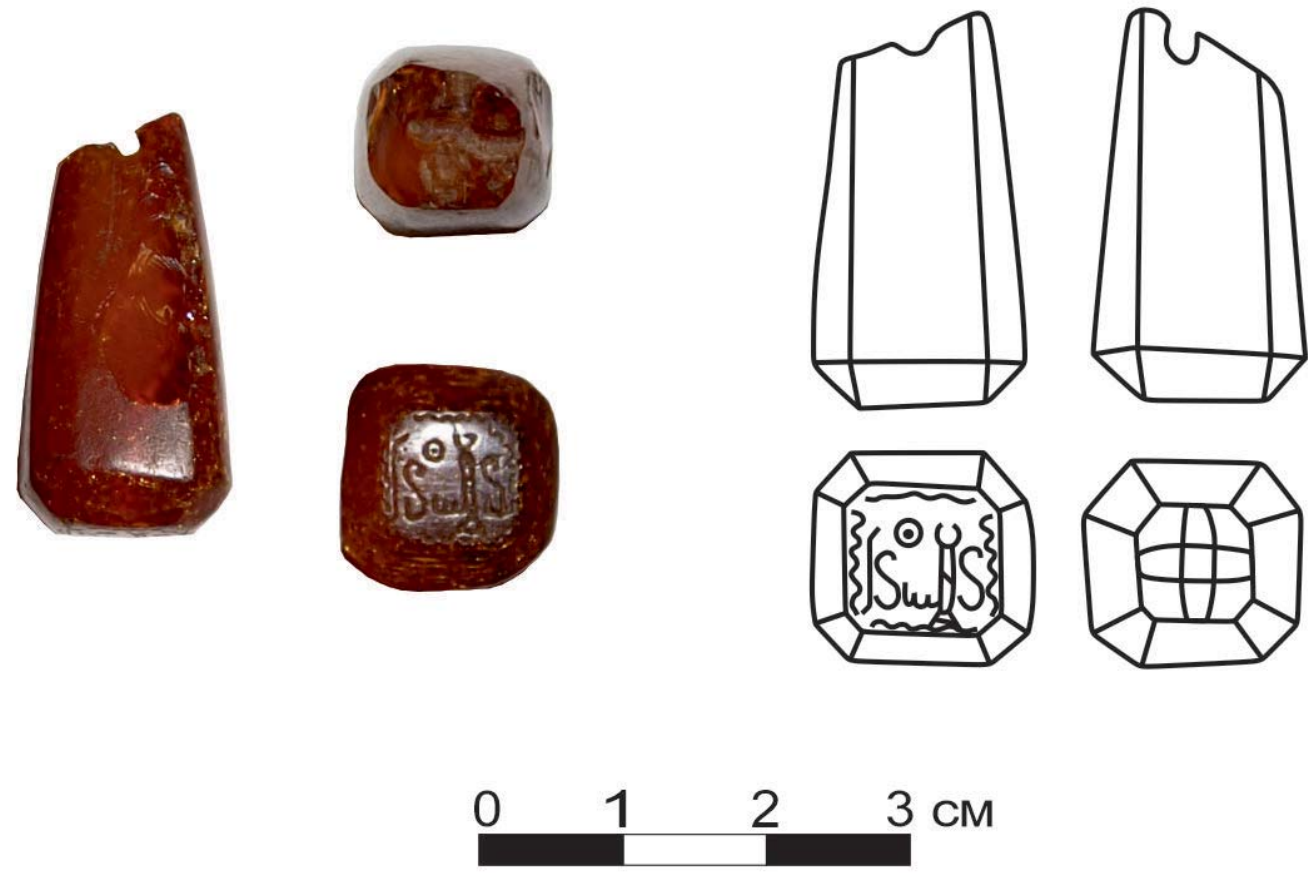

Рис. 1. Янтарная подвеска-печать с арабской надписью

Fig. 1. Amber pendant seal with an Arabic inscription

«Восточные тюрки... предпочитают янтарь румийский за его чистоту и блеск... и не ценят китайский...» (Бируни, 1963, с. 197). «Румийским» (византийским) Бируни называет прибалтийский янтарь, т. к. он попадал на Восток через Византию.

Практически весь прибалтийский янтарь - это сукцинит, который имеет золотистоили медово-желтый, оранжевый, красновато-коричневый, очень редко черный и белый, голубой и полосчатый цвета.

Янтарь с Балтийского побережья на Русь проникал тремя путями. Первый из них морской - из Балтийского моря по Неве, Ладожскому озеру и Волхову в Старую Ладогу, Новгород и Старую Руссу. Второй путь с побережья вглубь Руси шел по Западной Двине. Этим же путем поступал янтарь в Полоцк, Витебск, Смоленск. По-видимому, весьма оживленным был и третий путь сухопутный тракт с Балтийского побережья к Пскову. Перечисленные города были основными центрами, из которых прибалтийский янтарь поступал в другие города, в том числе и в Волжскую Булгарию (Розенфельдт, 1978, с. 198).
Еще до проникновения арабского алфавита, булгары пользовались рунической графикой, близкой к тюрко-орхонской. Известны такие надписи в Среднем Поволжье и Прикамье. Они обнаружены на камне, найденном у поселка Юрино Марийской области, на серебряных изделиях XI-XII вв., на сфероконусах, на керамической посуде и некоторых других предметах. Впоследствии многие руны перешли в область тамг и знаков. Четко датированные нумизматические материалы IX-X вв. подтверждают раннее проникновение и распространение арабской графики (Давлетшин, 1990, стр. 113-114). Также арабские надписи появляются на различных изделиях, от раннебулгарских до домонгольских: перстни со вставками и без них, пирофиллитовые и глиняные напрясла, фрагмент костяной пластинки составного лука, сфероконусы, кувшины, украшения (Казаков, 1985). Особый интерес представляет замок мастера Абу Бекра (НМРТ, КП № 5693) с арабской благопожелательной надписью и с точной датой гравировки - 1146/47 гг. Первый исследователь этого замка, С.Е. Малов, отмечает: «Мне хотелось бы думать, что замок этот болгарско- 
билярского, а не привозного (из Азии) происхождения. К этому ведет мысль, как общий характер выделки замка, так и орнамент на нем» (Малов, 1927).

Наличие среди булгарских археологических материалов часто встречающихся печатейпломб или перстней с именами владельцев свидетельствует о развитии учётно-расписочной и документационной системы.

В целом эпиграфические материалы домонгольской Волжской Булгарии достаточно немногочисленны, и любые предметы с надписями имеют большую научную значимость. Большинство таких надписей выполнено ремесленниками. Этот факт свидетельствует о значительном распространении элементарной грамотности среди населения. А также выявление и расшифровка надписей способствуют решению многих проблем происхождения, этнического состава, языка и политической истории волжских булгар. Судя по качеству обработки и достаточно тщательному начертанию надписи, а также по немногочисленным аналогиям, датировать данную подвеску-печать можно предположительно второй половиной XII - началом XIII вв.

Благодарности: выражаю огромную благодарность сотрудникам отдела изобразительных и документальных источников Национального музея РТ (г. Казань) Р.А. Абзалиной, Л. Шаймардановой и Л. Губаевой за помощь в прочтении надписи.

\section{Примечания:}

${ }^{1}$ Сафия переводится как "чистая, прозрачная; избранница, искренняя подруга". Так звали одну из жен Пророка, его тетю и нескольких других сподвижниц

\section{ЛИТЕРАТУРА}

Ахмаров Г.Н. Экскурсия на место древнего Сувара // ИОАИЭ. Т.11. Вып. 1-6. Казань, 1893.

Бируни. Собрание сведений для познания драгоценностей (Минералогия) / пер. А. М. Беленицкого; ст. и примеч. А. М. Беленицкого и Г. Г. Леммлейна. Л.: АН СССР, 1963. 521 с.

Давлетшин Г.М. Волжская Булгария: духовная культура (домонгольский период, X-нач.XIII вв.) Казань: Татарское кн.изд-во, 1990. 192 с.

Казаков Е.П. Знаки и письмо ранней Волжской Булгарии по археологическим данным // СА. 1985. № 4. C. $178-185$.

Малов C.E. Замок из Билярска с арабской надписью // Записки Коллегии Востоковедов при Азиатском музее Академии наук СССР. Т.ІІ. - Л.: АН СССР, 1927. С. 155-162.

Розенфельдт Р.Л. Янтарь на Руси // Проблемы советской археологии / Ред. В.В. Кропоткин, Г.Н. Матюшин, Б.Г. Петерс. М.: Наука, 1978. С. 197-208.

Смирнов А.П. Сувар. Итоги раскопок 1933-1937 гг. // Работы археологических экспедиций / Труды ГИМ. Вып. 16. / Ред. Д. Н.Эдинг. М.: ГИМ, 1941. С. 135-171.

Хузин Ф.Ш., Кочкина А.Ф. Города - центры земель-княжеств // История татар с древнейших времен в семи томах. Т. ІІ. Волжская Булгария и Великая степь / Отв. ред. Ф.Ш. Хузин. Казань: РухИЛ, 2006. C. $180-189$.

\section{Информация об авторе:}

Губайдуллина Антонина Викторовна, старший научный сотрудник, Национальный музей Республики Татарстан (г.Казань, Россия); antonina.gubaidullina@mail.ru

\section{REFERENCES}

Akhmarov, G. N. 1893. In Izvestiia obshchestva arkheologii, istorii i etnografii pri Kazanskom imperatorskom universitete (Reports of the Society of Archaeology, History and Ethnography Affiliated with Kazan Imperial University) XI (1-6). Kazan, (in Russian).

Biruni. 1963. Sobranie svedenii dlia poznaniia dragotsennostei (Mineralogiia) (Collection of Knowledge for the Study of Jewelry (Mineralogy)). Leningrad: Academy of Sciences of the USSR (in Russian).

Davletshin, G. M. 1990. Volzhskaia Bulgariia: dukhovnaia kul'tura (Domongol'skii period, X-nach. XIII vv.) (Volga Bolgaria: Spiritual Culture (Pre-Mongol Period, 10th-Early 13th Centuries)). Kazan: "Tatarskoe knizhnoe izdatel'stvo" Publ. (in Russian).

Kazakov, E. P. 1985. In Sovetskaia Arkheologiia (Soviet Archaeology) (4), 178-185 (in Russian). 
Malov, S. E. 1927. In Zapiski Kollegii Vostokovedov pri Aziatskom muzee Akademii nauk SSSR (Notes of the College of Orientalists at the Asian Museum) II. Leningrad: Academy of Sciences of the USSR, 155-162 (in Russian).

Rozenfeldt, R. L. 1978. In Kropotkin, V. V., Matyushin, G. N., et al. (eds.). Problemy sovetskoi arkheologii (Issues of Soviet Archaeology). Moscow: "Nauka" Publ., 197-208 (in Russian).

Smirnov, A. P. 1941. In Eding, D. N. (ed.). Raboty arkheologicheskikh ekspeditsii (Works by Archaeological Expeditions). Series: Proceedings of the State Historical Museum 16. Moscow: State Historical Museum, 135-171 (in Russian).Khuzin, F. Sh., Kochlina, A. F. 2006. In Khuzin, F. Sh. (ed.). Istoriia tatar s drevneishikh vremen $v$ semi tomakh (History of the Tatars since Ancient Times in seven volumes. 2. Kazan: "Rukhil" Publ., 180-189 (in Russian).

\section{About the Author:}

Gubaidullina Antonina V. National Museum of the Republic of Tatarstan. Kremlyovskaya St., 2, Kazan, 420111, the Republic of Tatarstan, Russian Federation; antonina.gubaidullina@mail.ru

Статья поступила в журнал 01.10.2021 г.

Статья принята к публикации 01.12.2021 г. 